\title{
PHENOLOGY, GROWTH AND POD YIELD OF FRENCH BEAN (Phaseolus vulgaris L.) AS INFLUENCED BY TEMPERATURE VARIATIONS UNDER DIFFERENT SOWING DATES
}

\author{
S.S.Kakon*, M.A.K. Mian, R.R.Saha, S.S.Nasreen ${ }^{1}$, Q.Naher ${ }^{2}$ and M.A.Hossain ${ }^{2}$ \\ Agronomy Division, Bangladesh Agricultural Research Institute (BARI) \\ ${ }^{1}$ Regional Agricultural Research Station, Akborpur, Moulvibazar \\ ${ }^{2}$ On-farm Research Division, BARI, Gazipur \\ "Corresponding Author, E-mail: kakonbari@gmail.com
}

(Received: 7 January 2019, Accepted: 23 March 2019)

Keywords: Temperature, french bean, phenology, growth and pod yield

\begin{abstract}
The experiment was conducted at the research field of the Agronomy Division, Bangladesh Agricultural Research Institute (BARI), Bangladesh during rabi season of 2017-2018 to evaluate the flowering behavior and pod yield of French bean. Three varieties namely BARI Jharsheem-1, BARI Jharsheem-2 and BARI Jharsheem-3 were sown on 30 November, 15 December and 30 December, respectively for getting temperature variation. Sowing dates based on temperature variation, significantly affect the flowering behaviour and pod yield of French bean varieties. Developmental events were badly affected when sown on 30 December. Crop accumulated lower GDD for different development events when sown late. Flowering duration of 30 November sowing were longer due to prevailing low temperatures (Min. $10.3-11.4^{\circ} \mathrm{C}$ and Max $23.7-24.5^{\circ} \mathrm{C}$ ) (Table 2). On the contrary, minimum flowering duration was recorded in 30 December sown crop (11-17 days). Minimum duration might be due to prevailing high temperature (Min.14.9-15.3 ${ }^{\circ} \mathrm{C}$ and Max 27.6-28.8 ${ }^{\circ} \mathrm{C}$ ) that shorten the flowering duration of all French bean varieties. Pod yield of all the varieties were more at November sowing and decreased towards late sowing. November 30 sowing performed better in relation to yield components and yield which was very close to 15 December sowing. BARI Jharsheem-1 produced the highest pod yield $\left(16.77 \mathrm{t} \mathrm{ha}{ }^{-1}\right)$ in 30 November sowing. French bean had been sown on November to December showed the greater variability in respect of flowering, flowering duration and the number of pods. The results revealed that November would be the optimum sowing date (15 Nov.-30 Nov.) for maximum pod yield of french bean var. BARI Jharsheem- 1 .
\end{abstract}

\section{Introduction}

French bean (Phaseolus vulgaris) is popularly known as Rajma, haricot bean, kindey bean, snap bean, navy bean, field bean, dry bean, pole bean etc and it is also known as 'Jhar sheem' in Bangladesh. French-bean is one of the important legume crops worldwide for direct human consumption. Due to its wide spread utilization of both the green pods and dried seeds. Green pods are rich in vitamins, protein and minerals. Besides this, a huge amount of French bean is consumed as soup. Its demand especially to the urban people is increasing day by day. The growth and development of any crop is primarily governed by the environmental conditions of the soil and climate. Sowing time of any crop depends on environmental conditions; mainly air temperature and rainfall greatly affect the growth and development of bean plants (Szyrmer et al., 
1992; Gross and Kigel, 1994; Mouhouche et al., 1998; Ibarra - Perez et al., 1999). The sowing times has marked effects on growth and yield of most crops in different parts of the world as delay in sowing beyond the optimum time usually results in yield reduction (Vange and Obi, 2006). Late sowing is one of the major causes of low yield of French bean. In Bangladesh, French bean is usually cultivated after harvesting of $T$. aman. But sowing time of French bean sometimes delayed due to late harvesting of $\mathrm{T}$. aman, as a result the crop face higher temperature during its reproductive stage.

Temperature based agro-climatic indices such as growing degree days (GDD) can be quite useful in predicting growth and yield of any crop. Growing degree days are based on the concept that, real time to attain a phenological stage is linearly related to temperature range between base temperature (Tb) and optimum temperature.

According to Wilczek and Ćwintal (2003), very high air temperatures and low rainfall much shortened the period of red clover flowering, whereas low temperatures along with high and frequent precipitation resulted in the prolongation of the plant's flowering even to 40-50 days. Wallace et al. (1991) also proved a significant shortening of the period to the beginning of plant flowering along with the increase of air temperature in the range of $12-28{ }^{\circ} \mathrm{C}$. The mean temperature requirement for optimum growth of French bean has been reported to be $14-24{ }^{\circ} \mathrm{C}$ (Kay, 1979), 16-30 ${ }^{\circ} \mathrm{C}$ (Nonneck, 1989) and 15-25 ${ }^{\circ} \mathrm{C}$ (Rashid, 1999). Heitholt et al. (1986) also reported that late flowers aborted more frequently than did early flowers in soybean. Pod abscission was increased by delay sowing which was accordance with Fisher (1980).

High temperature stress causes substantial loss in crop yield due to the damage of reproductive organs (Savin and Nicolas, 1996) and reduced length of reproductive period. So, it is now essential to study the crop growth behaviors in changing climatic condition for future requirement. Therefore, the present experiment was conducted to evaluate the growth and development, flowering behaviour and pod yield under different temperature variation from different sowing time.

\section{Materials and Methods}

The experiment was conducted at the Agronomy research field of Bangladesh Agricultural Research Institute, Bangladesh during rabi season of 2017-18. The experimental site was located at Chhiata Series under Agro-Ecological Zone-28 (AEZ-28), latitude $23^{\circ} 59^{\prime} \mathrm{N}$ and longitude $90^{\circ} 24^{\prime} \mathrm{E}$. Before opening the land, the soil samples were taken from the spots of the experimental area and analyzed from the Soil Science Division, BARI. The soil analysis showed that the soil of the experimental field was loam in texture and low in organic matter $(1.27 \%)$. The soil was acidic in nature with $\mathrm{pH} 6.1$ and contained very low amount of total nitrogen $(0.067 \%)$, phosphorus $(9.6 \%)$, sulphur (12\%), zinc (2 meq $/ 100 \mathrm{~g})$ and medium amount of potassium $(0.18 \mathrm{meq} / 100 \mathrm{~g})$. The rainfall during the period was $42.0 \mathrm{~mm}$ in 2017-18. The 12 treatment combinations were studied. The main plot treatments consisted of three sowing dates viz. 15 November, 30 November, 15 December and 30 December while sub-plot treatments consisted of three varieties (BARI Jharsheem-1, BARI Jharsheem-2 and BARI Jharsheem-3). The experiment was laid out in a split- plot design with 3 replications. The unit plot size was $3.0 \mathrm{~m}$ प $3.0 \mathrm{~m}$. The crop was fertilized with 120-40-60 -12-3 N-P-K-S-Zn ha ${ }^{-1}$, respectively (FRG, 2012). Half of $\mathrm{N}$ and full doses of other fertilizers were applied at the time of final land preparation and the rest urea was top dressed at 30 DAS. Seeds were treated with Vitavax 
and sown continuously in $30 \mathrm{~cm}$ apart rows. Plant to plant distance was maintained by $10 \mathrm{~cm}$. Hand weeding was done at 20 and 35 days after sowing (DAS). Pre sowing irrigation was given to the crop for uniform emergence. The crop was attacked by cutworm (Agroti sipsilon) and hairy caterpillar (Spilarctia obliqua) at early growth stage. The cutworm was controlled by hand picking. Perfecthion 40 EC @ $2.0 \mathrm{ml} \mathrm{L}^{-1}$ of water was sprayed at an interval of 7-10 days for 3 times to control hairy caterpillar. The phenological data were recorded by field monitoring every day. At each harvesting time, five plants were taken randomly from each plot to record the data on yield components. Growing degree days (GDD) were computed considering base temperature as $8{ }^{\circ} \mathrm{C}$ (Thavaprakaash et.al, 2007). In present study, a different thermal index like growing degree days (GDD) was calculated to find the relationship of these thermal indices with different phenological stages. The agro-climatic indices were computed as follows:

Growing degree day $(\mathrm{GDD})=\{(\mathrm{T} \max +\mathrm{T} \min ) / 2\}-\mathrm{Tb}, \quad$ here, $\mathrm{Tb}$ is base temperature

Pod yield was recorded from an area of $3 \mathrm{~m} \times 2 \mathrm{~m}$ avoiding border effect. Data on different parameters were subjected to analysis of variance and the treatment means were compared by Least Significant Difference (LSD) test.

\section{Results and Discussion}

\section{Duration and growing degree days for vegetative phase and crop growth duration of French bean}

Crop developmental events and growth duration were influenced by the interaction effects (Table 1) of sowing date and variety. Crop growth duration was recorded maximum in BARI Jharsheem -2 when sown on 30 November (69 days) with the highest GDD (977.35) followed by 15 December sowing (65 days) with the $2^{\text {nd }}$ highest GDD (914.25) and the second crop growth duration was recorded maximum in BARI Jharsheem-1 with the $2^{\text {nd }}$ highest GDD (945.85). The minimum duration (49 days) with minimum GDD (672.65) was recorded in BARI Jharsheem-3 at 30 December sowing. The reasons for variation in growth duration might be due to increased day and night temperature at later sowing (Fig. 1). The late sown crops flowered earlier with reduced vegetative durations than those of early sown ones. The highest duration for flowering was recorded in 30 November (21-24 days) sowing with maximum GDD (857.55-977.35). The lowest duration for flowering was recorded (11-17 days) with maximum GDD (672.65-818.40) in 30 December sowing. Similar result was also reported by Rangaswamy (1975).

Table 1. Required duration and growing degree days for crop development events and crop duration of French bean varieties by sowing date during rabi (2017-2018)

\begin{tabular}{lcccc}
\hline Sowing date $\times$ variety & \multicolumn{2}{c}{ Emergence } & \multicolumn{2}{c}{$\begin{array}{c}\text { Days to required .1st } \\
\text { flowering }\end{array}$} \\
\cline { 2 - 5 } & $\begin{array}{c}\text { Duration } \\
\text { (days) }\end{array}$ & GDD & $\begin{array}{c}\text { Duration } \\
\text { (days) }\end{array}$ & GDD \\
\hline $\mathrm{D}_{1} \times \mathrm{V}_{1}$ & 6 & 120.50 & 35 & 599.10 \\
$\mathrm{D}_{1} \times \mathrm{V}_{2}$ & 7 & 140.00 & 37 & 630.95 \\
$\mathrm{D}_{1} \times \mathrm{V}_{3}$ & 7 & 140.00 & 31 & 540.50 \\
$\mathrm{D}_{2} \times \mathrm{V}_{1}$ & 7 & 108.80 & 41 & 606.95 \\
$\mathrm{D}_{2} \times \mathrm{V}_{2}$ & 8 & 125.35 & 43 & 629.30 \\
$\mathrm{D}_{2} \times \mathrm{V}_{3}$ & 8 & 101.35 & 39 & 590.20 \\
$\mathrm{D}_{3} \times \mathrm{V}_{1}$ & 8 & 120.30 & 40 & 533.55
\end{tabular}




\begin{tabular}{|c|c|c|c|c|}
\hline $\begin{array}{l}\mathrm{D}_{3} \times \mathrm{V}_{2} \\
\mathrm{D}_{3} \times \mathrm{V}_{3} \\
\mathrm{D}_{4} \times \mathrm{V}_{1} \\
\mathrm{D}_{4} \times \mathrm{V}_{2} \\
\mathrm{D}_{4} \times \mathrm{V}_{3} \\
\end{array}$ & $\begin{array}{l}9 \\
8 \\
8 \\
9 \\
8 \\
\end{array}$ & $\begin{array}{c}134.70 \\
96.30 \\
109.30 \\
117.85 \\
109.30 \\
\end{array}$ & $\begin{array}{l}42 \\
39 \\
38 \\
35 \\
34 \\
\end{array}$ & $\begin{array}{l}561.80 \\
518.65 \\
490.90 \\
441.25 \\
426.35 \\
\end{array}$ \\
\hline \multicolumn{5}{|l|}{ Cont,d } \\
\hline \multirow[t]{2}{*}{$\begin{array}{c}\text { Sowing date } \times \\
\text { variety }\end{array}$} & \multicolumn{2}{|c|}{$\begin{array}{l}\text { Flowering duration } \\
\text { (Day) }\end{array}$} & \multicolumn{2}{|c|}{$\begin{array}{l}\text { Crop growth duration } \\
\text { (Day) }\end{array}$} \\
\hline & Duration (days) & GDD & $\begin{array}{c}\text { Duration } \\
\text { (days) }\end{array}$ & GDD \\
\hline $\mathrm{D}_{1} \times \mathrm{V}_{1}$ & 18 & 262.75 & 56 & 885.15 \\
\hline $\mathrm{D}_{1} \times \mathrm{V}_{2}$ & 21 & 281.15 & 61 & 937.25 \\
\hline $\mathrm{D}_{1} \times \mathrm{V}_{3}$ & 17 & 255.95 & 55 & 874.9 \\
\hline $\mathrm{D}_{2} \times \mathrm{V}_{1}$ & 24 & 302.00 & 67 & 945.85 \\
\hline $\mathrm{D}_{2} \times \mathrm{V}_{2}$ & 24 & 312.05 & 69 & 977.35 \\
\hline $\mathrm{D}_{2} \times \mathrm{V}_{3}$ & 21 & 252.65 & 61 & 857.55 \\
\hline $\mathrm{D}_{3} \times \mathrm{V}_{1}$ & 23 & 347.45 & 63 & 882.15 \\
\hline $\mathrm{D}_{3} \times \mathrm{V}_{2}$ & 22 & 280.65 & 65 & 914.25 \\
\hline $\mathrm{D}_{3} \times \mathrm{V}_{3}$ & 18 & 259.15 & 57 & 782.25 \\
\hline $\mathrm{D}_{4} \times \mathrm{V}_{1}$ & 17 & 287.85 & 57 & 818.4 \\
\hline $\mathrm{D}_{4} \times \mathrm{V}_{2}$ & 12 & 198.30 & 52 & 723.75 \\
\hline $\mathrm{D}_{4} \times \mathrm{V}_{3}$ & 11 & 177.40 & 49 & 672.65 \\
\hline
\end{tabular}

$\mathrm{V}_{1}=$ BARI Jharsheem $-1, \mathrm{~V}_{2}=$ BARI Jharsheem- $2, \mathrm{~V}_{3}=$ BARI Jharsheem- $3, \mathrm{D}_{1}=15$ November, 30 November, $\mathrm{D}_{2}=15$ December, $\mathrm{D}_{4}=30$ December.

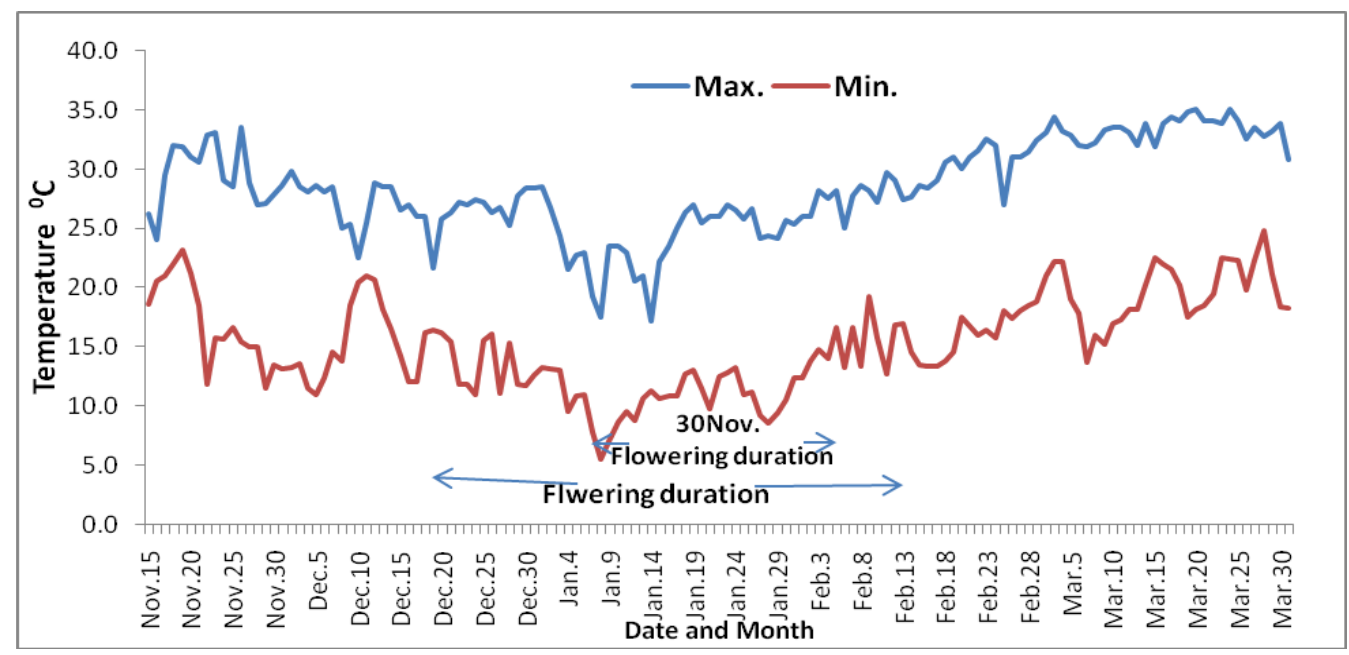

Fig. 1. Mean temperatures (Max. and min.) during crop growing period in 2017-18

Temperature is an important factor of flowering in French bean (Fig. 1). Flowering duration in all varieties was also observed maximum in 30 November sowing (21-24 days). Flowering duration of 30 November sowing were longer due to prevailing low temperatures (Min.10.3-11.4 ${ }^{\circ} \mathrm{C}$ and Max 23.7-24.5 ${ }^{\circ} \mathrm{C}$ ) (Table 2). On the contrary, minimum flowering duration was recorded in 30 December sown crop (11-17 days). Minimum duration might be due to prevailing 
high temperature (Min.14.9-15.3 ${ }^{\circ} \mathrm{C}$ and Max 27.6-28.8 ${ }^{\circ} \mathrm{C}$ ) that shorten the flowering duration of all French bean varieties. Similar results were also observed by Łabuda and Brodaczewska (2007).

Table 2. Prevailing average temperature during the duration of flowering of French bean varieties sown at different dates

\begin{tabular}{|c|c|c|c|c|c|c|}
\hline \multirow[t]{3}{*}{ Sowing Date } & \multicolumn{6}{|c|}{ Flowering duration } \\
\hline & BARI & Jharsheem-1 & BARI Jl & sheem-2 & BARI Jl & sheem-3 \\
\hline & $\begin{array}{c}\text { Max. } \\
\text { Tem. }{ }^{\circ} \mathrm{C}\end{array}$ & $\begin{array}{c}\text { Min. } \\
\text { Tem. }{ }^{\circ} \mathrm{C}\end{array}$ & $\begin{array}{c}\text { Max. } \\
\text { Tem. }{ }^{\circ} \mathrm{C}\end{array}$ & $\begin{array}{c}\text { Min. } \\
\text { Tem. }{ }^{\circ} \mathrm{C}\end{array}$ & $\begin{array}{c}\text { Max. } \\
\text { Tem. }{ }^{\circ} \mathrm{C}\end{array}$ & $\begin{array}{c}\text { Min. } \\
\text { Tem. }{ }^{\circ} \mathrm{C}\end{array}$ \\
\hline 15 & 25.90 & 13.00 & 25.1 & 11.5 & 26.6 & 13.6 \\
\hline $\begin{array}{c}\text { November } \\
30\end{array}$ & 24.5 & & 24.8 & 11.4 & 23.7 & 10.3 \\
\hline $\begin{array}{c}\text { November } \\
15\end{array}$ & 26.9 & 10.9 & 26.9 & 13.5 & 26.4 & 12.9 \\
\hline $\begin{array}{c}\text { December } \\
30 \\
\text { December }\end{array}$ & 28.8 & $\begin{array}{l}13.4 \\
15.3\end{array}$ & 27.7 & 15.3 & 27.6 & 14.9 \\
\hline
\end{tabular}

\section{Total dry matter}

The yield of a crop is mainly determined by the accumulation of DM and its partitioning into the economic sink. At flowering stage, the total dry matter production of French bean varieties varied due to different sowing dates (Fig. 2). Significantly the highest total dry matter $\left(8.93 \mathrm{~g} \mathrm{plant}^{-1}\right)$ was obtained in BARI Jharsheem-2 had been sown on 30 November. The lowest total dry matter (4.02 $\mathrm{g}$ plant $^{-1}$ ) was recorded in BARI Jharsheem-2 had been sown at 30 December.

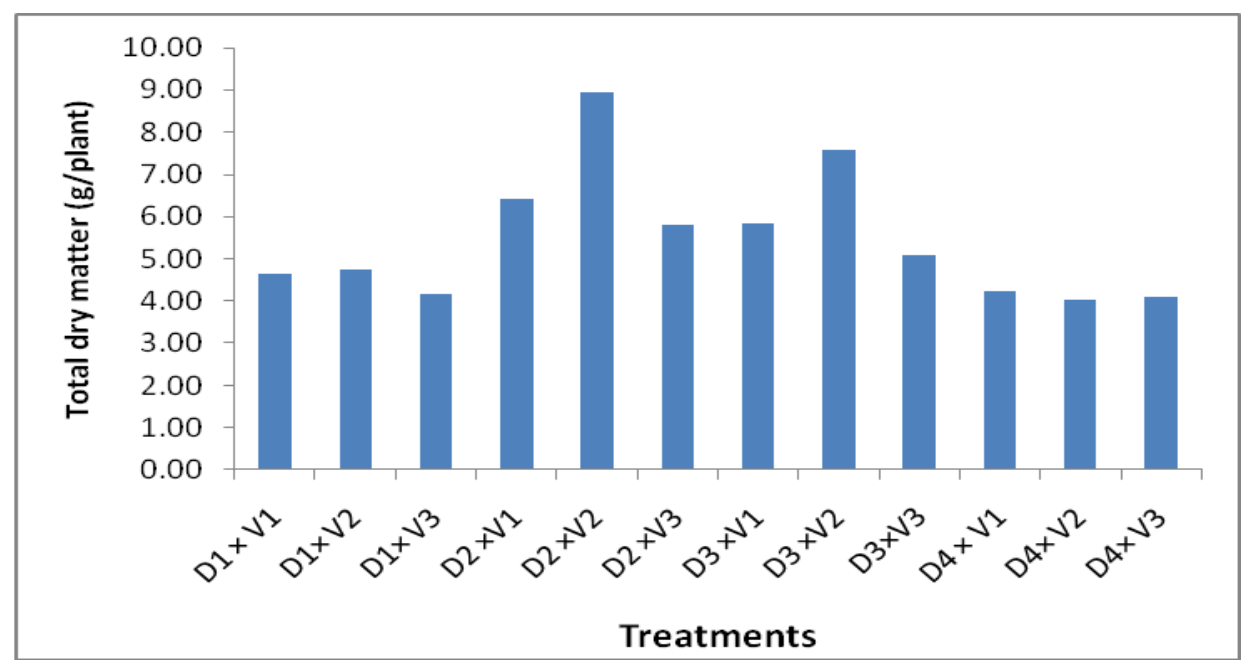

Fig. 2. Total dry matter production of French bean varieties at flowering stage under different sowing date.

$\mathrm{V}_{1}=$ BARI Jharsheem $-1, \mathrm{~V}_{2}=$ BARI Jharsheem- $2, \mathrm{~V}_{3}=$ BARI Jharsheem-3, $\mathrm{D}_{1}=15$ November, 30 November, $\mathrm{D}_{2}=15$ December, $\mathrm{D}_{4}=30$ December.

Yield and yield components

Yield and yield attributes of French bean varieties were significantly affected by sowing dates (Table 3). BARI Jharsheem-1 produced the tallest plant $(45.93 \mathrm{~cm})$ in 30 November sowing. The shortest plant $(25.47 \mathrm{~cm})$ was obtained in BARI 
Jharsheem-2 when crop sown on 30 December. Significantly the highest number of pods plant ${ }^{-1}$ (16.28) was recorded the in BARI Jharsheem-1 had been sown on 30 November which was statistically similar to that of same sowing with variety BARI Jharsheem-2. The lowest number of pods plant $^{-1}(6.45)$ was obtained in BARI Jharsheem-2 sown on 30 December due to high temperature. It could be noted that 30 December sown plants experienced high temperature (Fig.1) during flowering period which caused fewer flower. The flowers were weathered and dried. 30 November sowing received lower day and night temperature during cropping period that caused longer crop growth duration and ultimately produced more TDM and translocation of more TDM to pods. On the other hand, 30 December sowing received higher day and night temperature that hastened maturity and reduced TDM production and translocation of less TDM to the reproductive organ.

Pod yield decreased with delay sowing. Significantly the highest pod yield $(16.77 \mathrm{t}$ $\mathrm{ha}^{-1}$ ) was recorded in BARI Jharsheem-1 in 30 November sowing. The lowest pod yield (7.34 $\mathrm{t} \mathrm{ha}{ }^{-1}$ ) was produced in BARI Jharsheem-2 from 30 December sowing. Sabale et al. (2010) was also found similar differences in the performance of bush beans under different dates of sowing. The highest yield was obtained from optimum sowing probably due to favourable climate possibly optimum temperature resulting better vegetative growth of the plants which ultimately led to the better flowering, fruit set and increased pod yield, which is in agreement with the findings of Mohanty et al. (2001) and Nielsen (2002).

Pod yield was possibly reduced due to increase in temperature over 30 November sowing. Pod yield of French bean would be decreased at the rate of $252 \mathrm{~kg} \mathrm{ha}{ }^{-1}$ day $^{-1}$ for 30 November sowing. Several researcher found that the decreased yield of French bean due to delay planting (Singh and Singh 1987; Ali 1989).

Table 3. Yield and yield components of different French bean varieties under different sowing dates during 2017-18

\begin{tabular}{lcccc}
\hline Treatments & $\begin{array}{c}\text { Plant } \\
\begin{array}{c}\text { population } \\
\left(\mathrm{m}^{-2}\right)\end{array}\end{array}$ & $\begin{array}{c}\text { Plant height } \\
(\mathrm{cm})\end{array}$ & $\begin{array}{c}\text { Pods plant } \\
(\text { no. })\end{array}$ & $\begin{array}{c}\text { Pod yield }^{-1} \\
(\mathrm{t} \mathrm{ha})^{-1}\end{array}$ \\
\hline $\mathrm{D}_{1} \times \mathrm{V}_{1}$ & 22.00 & 44.37 & 13.55 & 14.84 \\
$\mathrm{D}_{1} \times \mathrm{V}_{2}$ & 21.00 & 40.00 & 12.89 & 13.64 \\
$\mathrm{D}_{1} \times \mathrm{V}_{3}$ & 21.00 & 43.63 & 10.03 & 9.93 \\
\hline $\mathrm{D}_{2} \times \mathrm{V}_{1}$ & 22.00 & 45.93 & 16.28 & 16.77 \\
$\mathrm{D}_{2} \times \mathrm{V}_{2}$ & 21.00 & 41.33 & 15.27 & 15.44 \\
$\mathrm{D}_{2} \times \mathrm{V}_{3}$ & 21.00 & 44.27 & 11.33 & 10.86 \\
\hline $\mathrm{D}_{3} \times \mathrm{V}_{1}$ & 21.33 & 39.00 & 14.16 & 14.67 \\
$\mathrm{D}_{3} \times \mathrm{V}_{2}$ & 22.33 & 38.50 & 13.53 & 13.13 \\
$\mathrm{D}_{3} \times \mathrm{V}_{3}$ & 22.33 & 36.29 & 9.97 & 10.22 \\
\hline $\mathrm{D}_{4} \times \mathrm{V}_{1}$ & 21.67 & 29.23 & 11.23 & 12.50 \\
$\mathrm{D}_{4} \times \mathrm{V}_{2}$ & 20.67 & 25.47 & 6.45 & 7.34 \\
$\mathrm{D}_{4} \times \mathrm{V}_{3}$ & 21.33 & 28.67 & 7.51 & 8.82 \\
\hline $\mathrm{LSD}(0.05)$ & $\mathrm{NS}$ & 4.78 & 5.99 & 4.55 \\
\hline $\mathrm{CV}(\%)$ & 5.10 & 1.824 & 1.23 & 0.973 \\
\hline
\end{tabular}

$\mathrm{V}_{1}=$ BARI Jharsheem $-1, \mathrm{~V}_{2}=$ BARI Jharsheem-2, $\mathrm{V}_{3}=$ BARI Jharsheem-3, $\mathrm{D}_{1}=15$ November, 30 November, $\mathrm{D}_{2}=15$ December, $\mathrm{D}_{4}=30$ December

\section{Conclusion}

French bean varieties sown on November to December showed variability in respect of the flowering, flowering duration, number of pods setting and pod 
yield. But November sowing would be the optimum time for getting maximum pod yield from BARI Jharsheem-1.

\section{References}

Ali, M. 1989. Response of Frenchbean genotypes to planting dates during winter season. Indian J. Pulses Res. 2(1): 59-63.

Fisher, N. M. 1980. The effect of time on planting on four beans (Phaseolus vulgaris) genotypes in Kenya. J. Agric. Sci. Cambodia. 59(2): 401-408. Gross, Y. and J. Kigel. 1994. Differential sensitivity to high temperature of stages in the reproductive development of common bean (Phaseolus vulgaris L.). Field Crops. Res. for pollinating insects. Acta Horti. 288: 321325.

Heitholt, J. J., D. B. Egli and Leggett, J. E. 1986. Characteristics of reproductive abortion in soybean. Crop Sci. 26: 589-595.

Ibarra-Perez, F. J., D. Barnhart, B. Ehdaie, K. M. Knio and J. G. Waines. 1999. Effects of Insect Tripping on Seed Yield of Common Bean. Crop. Sci. 39: 428-433.

Kay, D. E. 1979. Haricot bean (Phaseolus vulgaris L .) crop and produc. Digest No. 3-Food Legumes. P.127.

Mohanty, S. K., B. Baisakih, U. K. Dikshit and B. Bhol. 2001. Kalamung, a promising local mungbean cultivar. Environ. Ecol. 16(1): 222-223.

Mouhouche, B., F. Ruget and R. Delŭcolle. 1998. Effects of water stress applied at different phonological phases yield components of dwarf bean (Phaseolus vulgaris L.). Agron. 18: 197-205.

Nonnecke, R. Vegetables Production. Van Notrand Reinhold. New York, USA, 1989.

Rangaswamy, G. (1975). Diseases of crop plants in India. Prentice Hall of India Put. Ltd., New Delhi.

Rashid, M. M. 1999. Shabjibiggayan (In Bengali). Rashid Pub. House, 94, Old DOHS, Dhaka-1206. pp. 418- 431.

Sabale, R. N., S. B. Wani and T. D. Dalvi (2010). Evaluation of sowing time for rabi French bean and validation by DSSAT-3.5. J. Maharashtra Agri. Univ. 35(3):480-482.

Savin, R. and M. E. Nicolas. 1996. Effect of short periods of drought and high temperature on grain growth and starch accumulation of two malting barley cultivars. Australian J. Plant Physiol. 23: 201-210.

Singh, R. C. and M. Singh 1987. Response of French bean (Phaseolus vulgaris L.) varieties to sowing time. Haryana Agric. Univ. J. Res. 17: 266-268.

Szyrmer, J., J. Dembińska and A. Wawer. 1992. Przebieg we- getacji i zmiennoś ćcechuż ytkowychodmian i form Phaseolus vulgaris L. / The vegetation pattern and variability of useful traits of cultivars and forms of Phaseolus vulgaris L. Biul. Inst. Hod. Aklim. Rośl. 180: 229 -239.

Thavaprakaash, N., R. Jagannathan, K. Velayudham and L. Gurusamy. 2007. Seasonal influence on phenology and accumulated heat units in relation to yield of baby corn. Int. J. Agric. Res. 2: 826-831.

Wallace D. H., P. A. Gniffke, P. N. Masaya and R. W. Zobel. 1991. Photoperiod, temperature, and genotype interaction effects on days and nodes required for flowering of bean. J. Amer. Soc. Hort. Sci. 116(3): 534-543. 
Wilczek M. and M. Ćwintal. 2003. Wpływ warunków pogodowych i glebowych na długoś ć kwitnienia nasiennej koniczyny czerwonej. / The in fluence of weather and soil conditions on red clover flowering length. Ann. Univ. Mariae Curie-Skłodowska, Sect. EEE Hortic. 13: 263 -269.

Vange, T. and I. U. Obi. 2006. Effect of planting date on some agronomic traits and grain yield of upland rice varieties at Makurdi, Benue State, Nigeria. J. Sustain. Dev. Agric. Env. 2(1): 1-9 (ISSN 0794-8867). 